\title{
EFFECT OF USING SODIUM FORMATE WITH RESTRICTED CALCIUM AND PHOSPHORUS ON BROILER PERFORMANCE AND GUT HEALTH
}

\author{
A.Y.M. Abdelhady; H.A. El-Alaily; S.A. Ibrahim and M.A.M. Abdelaziz \\ Poultry Production Department, Faculty of Agriculture, Ain Shams University, Egypt.
}

\section{SUMMARY}

$\mathrm{T}$ he present experiment was conducted to study effects of using different levels of sodium-di-formate (NDF) with different levels of restricted phosphorus in broiler diets on productive performance, carcass traits and gut health. At one day of age, 175 Hubbard chicks were divided into 7 groups (25 birds each). Each group contained 5 replicates of 5 birds each. The experimental groups were as follows:

1. Control diet contains $100 \% \mathrm{Ca}$ and available phosphorus (AP) requirements without NDF.

2. Diet contains $50 \%$ of $\mathrm{Ca}$ and $\mathrm{AP}$ requirements $+1.50 \mathrm{Kg} /$ ton NDF.

3. Diet contains $40 \%$ of $\mathrm{Ca}$ and AP requirements $+1.50 \mathrm{Kg} /$ ton NDF.

4. Diet contains $50 \%$ of $\mathrm{Ca}$ and $\mathrm{AP}$ requirements $+2.25 \mathrm{Kg} /$ ton NDF.

5. Diet contains $40 \%$ of $\mathrm{Ca}$ and AP requirements $+2.25 \mathrm{Kg} /$ ton NDF.

6. Diet contains $50 \%$ of $\mathrm{Ca}$ and $\mathrm{AP}$ requirements $+3.00 \mathrm{Kg} /$ ton NDF.

7. Diet contains $40 \%$ of $\mathrm{Ca}$ and $\mathrm{AP}$ requirements $+3.00 \mathrm{Kg} /$ ton NDF.

Main results obtained could be summarized as following:

1. There were no significant differences among all groups in live body weight (LBW) during starter period, while final LBW was superior with (T5) and (T7) groups. Also, no significant differences were noticed within all groups in daily weight gain (DWG) during starter period, while overall DWG was superior with birds fed (T5) or (T7) diet.

2. No significant differences among all experimental groups in daily feed consumption (DFC) during starter period, while birds of (T5) or (T7) groups consumed more feed during overall test period. Feed conversion ratio (FCR) values indicated that best FCR was recorded with chicks fed (T2), (T5) or (T7) diet during starter period, while overall FCR was found to be similar within all groups.

3. Values of both performance index (PI) and production efficiency factor (PEF) showed that all experimental groups are significantly similar to the control (T1) group.

4. Chicks fed (T5) or (T6) diet had better protein conversion ratio (PCR) and energy conversion ratio (ECR) values during starter period. While during overall period, PCR and ECR values of all test groups are significantly similar to those of control (T1) group.

5. All carcass traits were not significantly affected by different dietary treatments including dressing, giblets and abdominal fat percentages.

6. Chicks fed different dietary level of NDF showed obvious effect on all ileal microflora classes including lactic acid bacteria counts when compared to those fed control (T1) diet.

It could be concluded that incorporation of Formi ${ }^{\circledR} \mathrm{NDF}$ at 2.25 to $3.00 \mathrm{Kg} /$ ton, in broiler diets, had many

beneficial effects on different productive performance classes with no adverse effect on carcass traits or intestinal microbiological population.

Keywords: Organic salts, phosphorus, gut health, broilers and performance.

\section{INTRODUCTION}

Organic acids have made great contribution to poultry production profitability by enhancing intestinal micro-biota, mucosa and immune system, protein digestibility, pancreatic secretion (Adil et al., 2010), nutrient and mineral utilization and as a result, enhanced growth performance and feed efficiency (Denil et al., 2003). Various organic acids are used in the feed industry to improve feed hygiene by decontamination by avoiding recontamination (Martin and Maris, 2005; Ricke, 2005). However, Antogiovanni et al. (2007) and Garcia et al. (2007) reported that organic acids did not affect meat yield. Marcos et al. (2004) reported that broilers fed a mixture of formic and propionic acid at $0.25 \%$ and $0.5 \%$ concentration had better performance than chickens fed higher levels of the mixture $(1 \%, 2 \%)$. Dietary organic acids create acidic environment ( $\mathrm{pH} 3.5$ to 4.0) in gut that favors development of lactobacilli and inhibits the replication of Escherichia coli, Salmonella, and other gram-negative bacteria (Chowdhury et al., 2009). Dietary supplementation of organic acids increases the feed conversion ratio and bodyweight in broiler chicken (Gauthier, 2000) and reduces colonization of pathogens on the intestinal wall, thus 
prevents damage to the epithelial cells (Langhout, 2000). One of the first reports of improved broiler performance when diets were supplemented with single acids was for formic acid (Vogt et al., 1981). In poultry formic acid alone or a combination of formic acid with propionic acid (Bio-Add ${ }^{\mathrm{TM}}$ ) at concentrations of 0.6\% were effective against infection with Salmonella (Berchieri and Barrow, 1996). In caecal contents the number of Salmonella was reduced following addition of either $0.36 \%$ calcium formate or $0.5 \%$ formic acid (Izat et al., 1990). However, Waldroup et al. (1995) found a reduction of ceacal $\mathrm{pH}$ in relation to an addition of a formic acid/ propionic acid blend in concentrations of $1 \%$. Senkoylu et al. (2007) reported that a combination of formic and propionic acid increased villus height and decreased width contributed to more extended surface area available for nutrient absorption, although the crypt depth was found decreased. This result is different from that of Garcia et al. (2007) who found increased crypt depth adding $10,000 \mathrm{ppm}$ of formic acid in the feed. These authors also reported improved FCR with no significant body weight difference feeding 5,000 and 10,000 ppm formic acid, unlike Hernandez et al. (2006) and Acikgoz et al. (2011) who failed to observe any positive effect on performance of broiler chickens when formic acid was added to the feed or the drinking water, respectively. A combination of formic and propionic acid, though, as well as their ammonium salts were found to increase body weight gain and improve FCR (Spais et al., 2002; Senkoylu et al., 2007). Every organic acid has specific anti-microbial activity. Formic acid has wide antimicrobial activity and is effective against fungi and bacteria (Dibner and Buttin, 2002). Russell (1992) claimed that some microorganisms are more resistant to organic acids because they are capable of allowing their internal $\mathrm{pH}$ to decline. Additionally, Russell and Dien-Gonzalez (1998) attributed the resistance of Gram-positive bacteria to organic acids to higher intracellular potassium concentration that provides counteraction for the anions. On the other hand, pathogenic Gram-negative bacteria, like E. coli, Salmonella spp. and Campylobacter spp. are acid-sensitive and therefore, much more affected by the weak acids. In spite of this fact, there is an emerging potential that acid-sensitive bacteria can adapt in an acidified environment, surviving the acid shock through the production of protective proteins (Foster, 2001). Organic acid salts, particularly ammonium formate and calcium propionate, increased live weight and weight gain of broilers until day 21, but no significant differences compared to controls were observed on day 42, although FCR was improved (Paul et al., 2007). A new organic acid salt (sodium diformate, similar to potassium diformate) has been proven to be effective against pathogenic bacteria, including salmonella, along the whole gastro-intestinal tract (Lückstädt and Mellor, 2011).

Using plant feedstuffs in poultry diets, results in excretion of excess $\mathrm{P}$ that is bound with phytate in high levels and might cause ecologic contamination. Formulating low $\mathrm{P}$ diets for poultry, presents lower feed costs and less P excretion (Nahm and Carlson, 1998). Dietary level of Ca and P at their suggested concentrations is known to reduce utilization of phytate phosphorus (PP) (Schöuner et al., 1993; Qian et al., 1994). Recently, ecological and economic implication of excessive $\mathrm{P}$ in poultry feeds, and in excreta have become of serious concern (Henuk and Dingle, 2003). Adaptation of birds to a specific deficient nutrient has been widely known. In this regard, poultry responds to nutrient restriction by increasing absorption and utilization, which in turn, decreases excretion of restricted nutrient (Yan et al., 2005; Abdelaziz, 2011; Thabet et al., 2014; Abdelaziz et al., 2015). There is a clear evidence stating increased $\mathrm{PP}$ availability from plant feed ingredients at deficient concentrations of $\mathrm{P}$ (Onyango et al., 2006). On the other hand, Yan et al. (2001) found that broilers grown on a diet adequate in $\mathrm{P}(0.45 \%)$ and $\mathrm{Ca}(1.0 \%)$ up to 3 rd week only required $0.186 \%$ AP from 3rd to 6th week of age for maximum BWG. On contrary, Summers (1997) declared that dietary P levels can be reduced by up to $20 \%$ for most classes of poultry without any adverse effect on bird's performance. However, this is effective only in conjunction with attention to dietary $\mathrm{Ca}$ levels which can influence $\mathrm{P}$ absorption and retention. Low levels of Ca and NPP can be fed up to the finisher phase without retarding performance (Skinner et al., 1992a and 1992b).

The current study aimed to examine the effect of using different levels of organic acid salt with different levels of restricted phosphorus in broiler diets, on productive performance, carcass traits and gut health.

\section{MATERIALS AND METHODS}

\section{Experimental diets and birds:}

This study was carried out at poultry experimental unit, agricultural experiment and research station at Qanater, faculty of agriculture, Ain Shams University, Egypt. One hundred seventy-five Hubbard broiler chicks one-day-old were divided into seven treatment groups, 25 chicks each, every treatment contained five replicates of five birds each. Chicks were fed starter diet from 0 to 2 weeks of age and then fed 
grower diet from 3 weeks to the end of the trial at 5 weeks of age. The experimental groups were as follows:

1. Control diet contains $100 \% \mathrm{Ca}$ and available phosphorus (AP) requirements without $N D F$.

2. $50 \%$ of $\mathrm{Ca}$ and $\mathrm{AP}$ requirements $+100 \%$ recommended level $(1.50 \mathrm{Kg} /$ ton $) \mathrm{NDF}$.

3. $40 \%$ of $\mathrm{Ca}$ and $\mathrm{AP}$ requirements $+100 \%$ recommended level $(1.50 \mathrm{Kg} /$ ton $) \mathrm{NDF}$.

4. $50 \%$ of $\mathrm{Ca}$ and $\mathrm{AP}$ requirements $+150 \%$ recommended level $(2.25 \mathrm{Kg} /$ ton $) N D F$.

5. $40 \%$ of $\mathrm{Ca}$ and $\mathrm{AP}$ requirements $+150 \%$ recommended level $(2.25 \mathrm{Kg} /$ ton $) N D F$.

6. $50 \%$ of $\mathrm{Ca}$ and AP requirements $+200 \%$ recommended level $(3.00 \mathrm{Kg} /$ ton $) N D F$.

7. $40 \%$ of $\mathrm{Ca}$ and $\mathrm{AP}$ requirements $+200 \%$ recommended level $(3.00 \mathrm{Kg} /$ ton $) N D F$.

Chicks were raised in wire cage batteries. Feed and water were supplied ad-libitum. The experimental diets were formulated to be iso-caloric and iso-nitrogenous. The control diet was formulated to provide the nutrient requirements according to guidelines of NRC (1994). The composition and calculated chemical analysis of the experimental starter and grower diets are shown in Table (1) and Table (2), respectively. Formi ${ }^{\circledR}$ NDF is a product of ADDCON, GmbH, Germany, which is manufactured under patented technology and is a unique combination of formic acid and sodium formate. This additive is designed to be added to finish feed mix by about $1.5 \mathrm{~kg} /$ ton as feed acidifier.

\section{Growth performance:}

Live body weight (LBW) of each replicate was recorded, and average daily weight gain (DWG) also was calculated by subtracting initial LBW of birds in a certain stage from final LBW in the same stage. Average of daily feed consumption (DFC) was calculated from difference between weekly amount of feed provided for each replicate within treatments and residual quantity for same replicate. Feed conversion ratio (FCR) ( $\mathrm{g}$ feed/ g gain) was calculated in different stages as the amount of feed consumed, in grams, in a certain stage which is required to produce out one gram of weight gain in the same stage. Performance index (PI) was also determined according to North (1981), while production efficiency factor (PEF) was calculated according to Emmert (2000).

\section{Carcass traits and ileal $\mathrm{pH}$ :}

At 5 weeks of age, 5 birds from each treatment having LBW around the average of the group were selected and sacrificed by severing the carotid artery and the jugular vein. After slaughtering, bleeding and scalding, viscera were removed manually without disrupting of abdominal fat. Ileal $\mathrm{pH}$ value was determined at lower ileum using digital $\mathrm{pH}$ meter. Dressed carcasses and giblets were weighed independently. The dressing percentage (DP) was calculated by determining carcass weight (including the carcass fat) as a percent of LBW. Then relative percentages of giblets were calculated. Also, ready to cook (RTC) percentage was also determined as RTC \% = DP \% + giblets \%

\section{Microbiological and enzymology tests:}

At the time of slaughter test, 3 samples of lower ileum content $(2 \mathrm{~cm}$ from Meckel's diverticulum to ileo-caecal junction) for each treatment were taken in sterilized plastic 20-ml tubes and cooled until incubation. Then deferential microflora count of ileum content was enumerated. Samples were weighed and serially diluted in $0.9 \%$ saline, vortexed and $1 \mathrm{ml}$ of each sample was dispensed and spread on selective media in Petri dishes. Brilliant Green agar media was used for Salmonella and MacConkey agar media were used for E. coli. According to the method of Quinn et al. (1992), microbial suspension from each dilution of a particular sample was transferred through pour plate and incubated at $37^{\circ} \mathrm{C}$ for $24 \mathrm{~h}$. Then colonies were counted through colony counter. The total colony count was (expressed as $\log 10 \mathrm{cfu} /$ $\mathrm{g}$ of contents) determined by multiplying reciprocal of the dilution factor and average numbers of colonies. The microbial counts were determined as colony forming units (cfu) per gram of sample.

\section{Histological examinations}

Representative specimens of small intestine (ileum) for each group were flushed with saline solutions $(0.9 \% \mathrm{NaCl})$ to remove contents and fixed in $10 \%$ formalin-saline solution and prepared by the ordinary histological techniques to study the histological changes associated with the experimental treatments. Tissue samples from the ileum of approximately midway between Meckel's diverticulum and the ileoceacal junction. The samples were dehydrated with varying concentrations of alcohol and then embedded in paraffin wax. Then, rotary type microtome was used for cutting the paraffin sections. Transverse sections (4-5 microns, thickness) were taken, mounted on glass slides and stained with haematoxylin and eosin ( $\mathrm{H}$ and $\mathrm{E}$ ) stains for light microscopic examination according to the methods of Culling (1983). All sections were examined under light microscope provided with digital camera. And all values were measured using an image analyzer (Leica Microsystems Co., Ltd., Germany) according to methods of Abràmoff et al. (2004). 


\section{Statistical analysis:}

Statistical analysis was conducted using the General Linear Model (GLM) procedure of SAS (2004). Means were compared using Duncan's Multiple Range Test (Duncan, 1955) and levels of significance were set at minimum of $(\mathrm{P} \leq 0.05)$. The statistical model was:

Where:

$$
\mathrm{Yij}=\mu+\mathrm{Ti}+\mathrm{eij}
$$

Yij= observation of the parameter measured

$\mathrm{Ti}=$ effect of treatment (i: 1 to 6 )

$$
\begin{aligned}
& \mu=\text { overall mean } \\
& \text { eij= random error }
\end{aligned}
$$

\section{RESULTS AND DISCUSSION}

\section{Growth performance:}

Results presented in Table (3) showed that initial body weight of birds was significantly similar within all groups. Additionally, no significant differences were noticed among LBW values for all groups at the end of starter stage. On the other hand, values of final LBW showed that birds fed (T5) diet were significantly heavier than those fed any other diet except for those fed (T7) diet. Values of DWG indicated no significant differences within all groups during starter, while during grower stage or overall test period, birds fed (T5) diet gained significantly more weight than those of all groups diet except for those fed (T7) diet. DFC values showed no significant differences during starter stage, while DFC was significantly higher for (T4), (T5) and (T6) during grower and for (T5) and (T7) during overall test period. Values of FCR indicate that birds of (T2), (T5) or (T7) diet recorded better FCR during starter, whereas birds fed (T2) diets recorded worst FCR during grower phase. On the other hand, overall FCR appeared similar for all groups. When comparing birds of different groups, it is clear that no adverse effects were observed on LBW, DWG, DFC or FCR when Ca and AP levels were reduced in starter and grower diets. Results of productive performance are in agreement with those of Abdelaziz (2011) who stated that using low levels of around $50 \%$ of normal $\mathrm{Ca}$ and AP required, gave results nearly matching those of control group. Data of performance index (PI) presented in Table (4) implied that all experimental groups are significantly similar to the control (T1) group. The same trend was noticed regarding values of production efficiency factor (PEF), when birds fed (T3) diets recorded the worst PEF while still significantly similar to those fed the control (T1) diet. These data are in harmony with those of Abdelaziz et al. (2015) who stated that feeding broilers diets that is gradually restricted in Ca and AP below required levels, gave results nearly matching those fed normal levels. In general, current results are also in conformity with those of Thabet et al. (2014); Dhandu and Angel (2003) and Angel et al. (2000). Results that birds of (T5) and (T5) groups presented productive performance similar to those of control (T1) group (Tables, 3 and 4) would be justified by that (T2) that contains $50 \% \mathrm{Ca}$ and AP requirements, had overcome that deficiency (Abdelaziz, 2011) even without addition of NDF. Regarding (T5) that contains $40 \% \mathrm{Ca}$ and AP requirements, presented beneficial effects of NDF on mineral digestibility and consequently, gave performance comparable with that of control (T1) group. Impact of NDF supplementation to broiler diets on protein conversion ratio (PCR) and metabolizable energy conversion ratio (ECR), is illustrated in Table (5). Addition of NDF in broiler diets, had significant effect on both PCR and ECR values during starter period. It is clear that, chicks fed (T5) or (T6) diet had better PCR and ECR values during starter period, while, chicks fed other dietary treatments (T2, T3 or T7) had worse values, and those fed (T4) diet recoded values similar to those of control (T1) group. On the other hand, it was obvious (Table, 5) that PCR and ECR values during growing were not significantly affected by experimental treatments. Alternatively, during overall period, data implied that all test groups are significantly similar to control (T1) group. In this regard, better efficiency in converting crude protein and energy per gram gain could be explained by higher body weight gain of birds (Table, 3 ).

\section{Carcass traits:}

Data representing some carcass characteristics at 5 weeks of age are shown in Table (6). In regard to dressed carcass weight percentage (DP) and ready to cook percentage (RTC) (carcass weight + giblets weight), no significant differences were observed within all groups. As shown in Table (6), data of relative weights percentages of liver, gizzard, heart, total giblets and abdominal fat presented insignificant differences within all groups. Generally, data of carcass characteristics, dressing percentage are in conformity with those observed by several authors (Thabet et al., 2014 and Abdelaziz, 2011). Results of carcass traits being in general not significantly affected by dietary treatment, may justify birds' adaptation to $\mathrm{Ca}$ and AP dietary limitation (Abdelaziz et al., 2015) and also the ability of NDF to enhance mineral 
digestibility. In accordance with Chowdhury et al. (2009), when feed acidifier (NDF) is added, pH values of ileum (small intestine) was significantly reduced with all treatments when compared with control (T1) group (Table, 6), except for (T3) group.

\section{Intestinal microbiology:}

The data presented in Table (7) and Figure (1) showed the effect of different dietary treatments on total viable bacteria, coli-form lactic acid bacteria and salmonella counts in lower ileum segment of small intestine (mean $\log 10 \mathrm{CFU} / \mathrm{g}$ ). Lowest amount of mean $\log \mathrm{CFU} / \mathrm{g}$ of total bacteria was recorded for broiler fed (T5) compared to other groups. In addition, lowest amount of mean log CFU/ g of coliform bacteria was recorded for broiler fed (T6) or (T7) compared to those fed other diets. Chicks fed (T3) diet showed higher counts log CFU/g of lactic acid bacteria being lower when compared to control (T1) group. Regarding salmonella count, lowest amount of mean log CFU/g of salmonella was recorded for broiler fed (T7) compared to other groups. Obtained results guarantee the fact that formic acid and formic acid salts (NDF) have wide antimicrobial activity and they are used effectively against fungi and bacteria (Dibner and Buttin, 2002). Generally, mode of action of organic acids on bacteria in poultry involves entry of these acids into the bacterial cell causing bacterial membrane disruption and inhibition of essential metabolic reactions. As noticed from data (Table, 7), all microflora that are counted are affected by addition of NDF to diets, as Gram-negative bacteria, like E. coli and Salmonella spp. are acid-sensitive and therefore, much more affected by the weak acids (Russell and Dien-Gonzalez, 1998). By reviewing ph values detected in lower ileum segment (Table, 6), it is noticed that the lower $\mathrm{pH}$ value, the more affected microflora population. NDF here create acidic media which interrupt bacterial balance, and stress on intracellular $\mathrm{pH}$ homeostasis which causes the accumulation of toxic anions and bacteria cannot tolerate large internal and external $\mathrm{pH}$ variations which lead eventually to kill bacteria.

\section{CONCLUSION}

Finally, after reviewing all these results, it might be advisory to state that Formi ${ }^{\circledR}$ NDF would be suitable feed acidifier that enhances gut health of broiler without any adverse effect on performance and carcass traits. As well, Formi ${ }^{\circledR}$ NDF boosted $\mathrm{Ca}$ and AP utilization of broilers and therefore these minerals would be fed at levels close to requirements.

\section{REFERENCES}

Abdelaziz, M.A.M. (2011). Nutritional studies on phosphorus in broiler diets. Ph.D. Thesis, Faculty of Agriculture, Ain Shams University, Egypt.

Abdelaziz, M.A.M.; A.I. El-Faham and N.G.M. Ali (2015). Effect of using unified mix of calcium and phosphorus in broiler diets. Egypt. Poult. Sci. J., 35(2):489-502.

Abràmoff, M.D.; P.J Magalhães and S.J. Ram (2004). Image processing with ImageJ. Biophoton. Intl., 11 (7):36-42.

Acikgoz, Z.; H. Bayraktar and O. Altan (2011). Effects of formic acid administration in the drinking water on performance, intestinal microflora and carcass contamination in male broilers under high ambient temperature. Asian-Aust. J. Anim. Sci., 24:96-102.

Angel, R.; T.J. Applegate and M. Christman (2000). Effect of dietary non-phytate phosphorus (nPP) on performance and bone measurements in broilers fed a four-phase feeding system. Poult. Sci., 79(Suppl. 1):21-22.

Antogiovanni, M.; A. Buccioni; F. Petacchi; S. Leeson S. Minieri; A. Martini and R. Cecchi (2007). Butyric acid glycerides in the diet of broiler chickens: Effects on gut histology and carcass composition. Ital. J. Anim. Sci., 6:19-25

Adil, S.; T. Banday; G.A. Bhat; M.S. Mir and M. Rehman (2010). Effect of dietary supplementation of organic acids on performance, intestinal histo-morphology and serum biochemistry of broiler chicken. Vet. Med. Int., 2010:479-485.

Berchieri, A., Jr. and P.A. Barrow (1996). Reduction in incidence of experimental fowl thyphoid by incorporation of a commercial formic acid preparation (Bio-Add ${ }^{\mathrm{TM}}$ ) into poultry feed. Poult. Sci., 75:339-341.

Chowdhury, R.; K.M.S. Islam; M.J. Khan; M.R. Karim; M.N. Haque; M. Khatun and G.M. Pesti (2009). Effect of citric acid, avilamy-cin and their combination on the performance, tibia ash, and immune status of broilers. Poult. Sci., 88:1616-1622. 
Culling, C.F. (1983). Handbook of Histopathological and Histochemical Techniques, 3rd ed. London, Boston: Butterworth.

Denil, M.; F. Okan and K. Celik (2003). Effect of dietary probiotic, organic acid and antibiotic supplementation to diets on broiler performance and carcass yield, Pak. J. Nutr., 2:89-91.

Dhandu, A.S. and R. Angel (2003). Broiler non-phytin phosphorus requirement in the finisher and withdrawal phases of a commercial four-phase feeding system. Poult. Sci., 82:1257-1265.

Dibner, J.J. and P. Buttin (2002). Use of organic acids as a model to study the impact of gut microflora on nutrition and metabolism. J. Appl. Poult. Res., 11:453-463.

Duncan, D.B. (1955). Multiple range and Multiple F tests. Biometrics, 11:1-42.

Emmert, J. (2000). Efficiency of phase feeding in broilers. Proceeding, California Animal Nutrition Conference. Fresno California, USA.

Foster, J.W. (2001) Acid stress responses of salmonella and E. coli: survival mechanisms, regulation, and implications for pathogenesis. J. Microbiol., 39:89-94.

Garcia, V.; P. Catala-Gregory; F. Hernandez; M.D. Megias and J. Madrid (2007). Effect of formic acid and plant extracts on growth, nutrient digestibility, intestine mucosa morphology, and meat yield of broilers. J. Appl. Poult. Res., 16:555-562.

Gauthier, R. (2000). Intestinal health, the key to productivity (The case of organic acids) XXVII Convencion ANECA-WPDSA. Puerto Vallarta, Jal. Mexico, 56:4045-4050.

Henuk, Y.L. and J.G. Dingle (2003). Poultry manure: source of fertilizer, fuel and feed. World's Poult. Sci. J., 59:350-360.

Hernandez, F.; V. Garcia; J. Madrid; J. Orengo; P. Catala and M.D. Megias (2006). Effect of formic acid on performance, digestibility, intestinal histo-morphology and plasma metabolite levels of broiler chickens. Brit. Poult. Sci., 47:50-56.

Izat, A.L.; N.M. Tidwell; R.A. Thomas; M.A. Reiber; M.H. Adams; M. Colberg and P.W. Waldroup (1990). Effects of a buffered propionic acid in diets on the performance of broiler chickens and on the microflora of the intestine and carcass. Poult. Sci., 69:818-826.

Langhout, P. (2000). New additives for broiler chickens. Feed Mix, 24-27.

Lückstädt, C. and S. Mellor (2011). The use of organic acids in animal nutrition, with special focus on dietary potassium diformate under European and Austral-Asian conditions. Rec. Adv. Anim. Nutr., 18:123-130.

Marcos, M.V.; F. José; M. Machado; C. Sônia; M. Daróz and A. Mônica Maria (2004). Mixture of formic and propionic acid as additives in broiler feeds. Sci. Agric., 61:371-375.

Martin, H. and P. Maris (2005). An assessment of the bactericidal and fungicidal efficacy of seventeen mineral and organic acids on bacterial and fungal food industry contaminants. Sci. Aliments, 25:105127.

Nahm, K.H. and C.W. Carlson (1998). The possible minimum chicken nutrient requirements for protecting the environment and improving cost efficiency (A review). Asia-Austr. J. Anim. Sci., 11:755-768.

North, M.O. (1981). Commercial chicken. Production Annual, 2nd Edition, Av., Publishing Company I.N.C., West Post. Connecticut, USA.

NRC (1994). National Research Council. Nutrient Requirements of Poultry 9th ed. Composition of poultry feedstuffs. National Academy Press, Washington, DC, USA. P.p. 61-75.

Onyango, E.N.; E.K. Asem and O. Adeola (2006). Dietary cholecalciferol and phosphorus influence intestinal phytase activity in broiler chicken. Br. Poult. Sci., 47:632-639.

Paul, S.K.; G. Halder; M.K. Mondal and G. Samanta (2007). Effect of organic acid salt on performance and gut health of broiler chicken. J. Poult. Sci., 44:389-395.

Qian, H.; E.T. Kornegay; H.P. Veit; D.M. Denbow and V. Ravindran (1994). Effect of supplemental Natuphos phytase on tibial traits of turkeys fed soybean meal-based semi-purified diets. Poult. Sci., 73(Suppl.1):89

Quinn, P.J; M.E. Carter; B.K. Markey and G.R. Carter (1992). Clinical veterinary microbiology, Mosbyyear book Europe limited Lynton House, 7-12 Tavistock square, London, Pp: 61-65.

Ricke, S.C. (2005). Food safety control in the poultry industry. G.C. Mead ed. Woodhead Publishing in Food Science and Technology, Cambridge, UK.

Russell, J.B. (1992). Another explanation for the toxicity of fermentation acids at low pH: anion accumulation versus uncoupling. J. Appl. Bacteriol., 73:363-370.

Russell, J.B. and F. Diez-Gonzales (1998). The effects of fermentation acids on bacterial growth. Adv. Microb. Physiol., 39:205-234.

SAS Institute (2004). JMP Statistics and Graphics Guide, SAS Institute, Cary, NC. USA. 
Schöuner, F.J.; P.P. Hoppe; G. Schwarz and H. Wieshe (1993). Phousphorus balance of layers supplied with phytase from Asperigllus Niger. In: Vitamine Und Weitere Zusalzsoffe Bei Mensh Tierk Supoosium, Poult. Abstr., 20: 287 p.

Senkoylu, N.; H.E. Samli; M. Kanter and A. Agma (2007). Influence of a combination of formic and propionic acids added to wheat- and barley-based diets on the performance and gut histo-morphology of broiler chickens. Acta. Vet. Hung., 55:479-490.

Skinner, J.T.; A.L. Izat and P.W. Waldroup (1992a). Effects of removal of supplemental calcium and phosphorus from broiler finisher diets. J. Appl. Poult. Res., 1:42-47.

Skinner, J.T.; M.H. Adams; S.E. Watkins and P.W. Waldroup (1992b). Effects of calcium and nonphytate phosphorus levels fed during 42 to 56 days of age on performance and bone strength of male broilers. J. Appl. Poult. Res., 1:167-171.

Spais, A.B.; I.A. Giannenas; P. Florou-Paneri; E. Christaki and N.A. Botsoglou (2002). Effect of Genex, a feed additive containing organic acids and herb extracts, on the performance of broiler chickens. J. Hellenic. Vet. Med. Soc., 53:247-256.

Summers, J.D. (1997). Precision phosphorus nutrition. J. Appl. Poult. Res., 6:495-500.

Thabet, H.A.; M.A.M. Abdelaziz and M.I. Shourrap (2014). Effect of dietary restriction of calcium and phosphorus on broiler performance and tibia characteristics. Egypt. J. Nutr. Feeds, 17:301-314.

Vogt, H.; S. Matthes and S. Harnisch (1981). The influence of organic acids on performance of broilers and layers. Archiv für Geflügelkunde, 45:221-232.

Yan, F.; J.H. Kersey and P.W. Waldroup (2001). Phosphorus requirements of broiler chicks three to six weeks of age as influenced by phytase supplementation. Poult. Sci., 80:455-459.

Yan, F.; R. Angel; C. Ashwell; A. Mitchell and M. Christman (2005). Evaluation of the broiler's ability to adapt to an early moderate deficiency of phosphorus and calcium. Poult. Sci., 84:1232-1241. 
Table (1). Feed ingredients and chemical composition of diets presented to birds during starter phase (0-14 days of age).

\begin{tabular}{|c|c|c|c|c|c|c|c|}
\hline \multirow{2}{*}{ Ingredients } & \multicolumn{7}{|c|}{ Dietary Treatments } \\
\hline & 1 & 2 & 3 & 4 & 5 & 6 & 7 \\
\hline Yellow Corn (grains) & 52.790 & 55.410 & 55.830 & 55.335 & 55.755 & 55.260 & 55.680 \\
\hline Soybean Meal (44\%) & 30.800 & 31.750 & 31.750 & 31.750 & 31.750 & 31.750 & 31.750 \\
\hline Corn Gluten Meal (60\%) & 9.000 & 8.000 & 8.000 & 8.000 & 8.000 & 8.000 & 8.000 \\
\hline Soybean Oil & 2.570 & 2.000 & 2.000 & 2.000 & 2.000 & 2.000 & 2.000 \\
\hline Calcium Carbonate & 1.800 & 0.850 & 0.660 & 0.850 & 0.660 & 0.850 & 0.660 \\
\hline Mono-Calcium Phosphate & 1.820 & 0.630 & 0.400 & 0.630 & 0.400 & 0.630 & 0.400 \\
\hline Premix & 0.300 & 0.300 & 0.300 & 0.300 & 0.300 & 0.300 & 0.300 \\
\hline Salt $(\mathrm{NaCl})$ & 0.300 & 0.300 & 0.300 & 0.300 & 0.300 & 0.300 & 0.300 \\
\hline HCL Lysine & 0.340 & 0.320 & 0.320 & 0.320 & 0.320 & 0.320 & 0.320 \\
\hline DL- Methionine & 0.180 & 0.190 & 0.190 & 0.190 & 0.190 & 0.190 & 0.190 \\
\hline Anti-mycotoxins & 0.100 & 0.100 & 0.100 & 0.100 & 0.100 & 0.100 & 0.100 \\
\hline Formi ${ }^{\circledR} N D F$ (Sodium Di-Formate) & - & 0.150 & 0.150 & 0.225 & 0.225 & 0.300 & 0.300 \\
\hline Total & 100.000 & 100.000 & 100.000 & 100.000 & 100.000 & 100.000 & 100.000 \\
\hline Crude Protein $\%$ & 23.02 & 23.04 & 23.07 & 23.03 & 23.06 & 23.03 & 23.06 \\
\hline Metabolizable Energy Kcal/ Kg & 3004 & 3028 & 3042 & 3026 & 3040 & 3023 & 3037 \\
\hline Calcium \% & 1.000 & 0.500 & 0.400 & 0.500 & 0.400 & 0.500 & 0.400 \\
\hline Available Phosphorus \% & 0.500 & 0.250 & 0.200 & 0.250 & 0.200 & 0.250 & 0.200 \\
\hline Lysine \% & 1.400 & 1.40 & 1.40 & 1.40 & 1.40 & 1.40 & 1.40 \\
\hline Methionine \% & 0.60 & 0.60 & 0.60 & 0.60 & 0.60 & 0.60 & 0.60 \\
\hline Methionine + Cystein \% & 1.00 & 1.00 & 1.00 & 1.00 & 1.00 & 1.00 & 1.00 \\
\hline Price/ Ton (L.E.) & 3727 & 3675 & 3672 & 3693 & 3690 & 3710 & 3707 \\
\hline
\end{tabular}

Each 3 Kg of premix contains: Vitamins: A: 12000000 IU; Vit. D3 2000000 IU; E: 10000 mg; K3: 2000 mg; B1:1000 mg; B2: 5000 mg; B6:1500 mg; B12: 10 mg; Biotin: 50 mg; Coline chloride: 250000 mg; Pantothenic acid: 10000 mg; Nicotinic acid: 30000 mg; Folic acid: 1000 mg; Minerals: Mn: 60000 mg; Zn: 50000 mg; Fe: 30000 mg; Cu: 10000 mg; I: 1000 mg; Se: $100 \mathrm{mg}$ and Co: $100 \mathrm{mg}$.

(T1):Control, (T2): $50 \% \mathrm{Ca} \& \mathrm{AP}$ requirements $+1.50 \mathrm{Kg} /$ ton $\mathrm{NDF} ;(\mathrm{T3}): 40 \% \mathrm{Ca} \& \mathrm{AP}$ requirements $+1.50 \mathrm{Kg} /$ ton $\mathrm{NDF} ;(\mathrm{T} 4): 50 \% \mathrm{Ca} \& \mathrm{AP}$ requirements $+2.25 \mathrm{Kg} /$ ton $\mathrm{NDF}(\mathrm{T5}):$ $40 \% \mathrm{Ca} \& \mathrm{AP}$ requirements $+2.25 \mathrm{Kg} /$ ton NDF; (T6): $50 \% \mathrm{Ca} \& \mathrm{AP}$ requirements $+3.00 \mathrm{Kg} /$ ton NDF and (T7): $40 \% \mathrm{Ca} \& \mathrm{AP}$ requirements $+3.00 \mathrm{Kg} /$ ton $\mathrm{NDF}$. 
Egyptian J. Nutrition and Feeds (2015)

Table (2). Feed ingredients and chemical composition of diets presented to birds during grower phase (15-35 days of age).

\begin{tabular}{|c|c|c|c|c|c|c|c|}
\hline \multirow{2}{*}{ Ingredients } & \multicolumn{7}{|c|}{ Dietary Treatments } \\
\hline & 1 & 2 & 3 & 4 & 5 & 6 & 7 \\
\hline Yellow Corn (grains) & 55.110 & 57.410 & 57.800 & 57.335 & 57.725 & 57.260 & 57.650 \\
\hline Soybean Meal (44\%) & 30.000 & 31.000 & 31.000 & 31.000 & 31.000 & 31.000 & 31.000 \\
\hline Corn Gluten Meal (60\%) & 6.000 & 5.000 & 5.000 & 5.000 & 5.000 & 5.000 & 5.000 \\
\hline Soybean Oil & 4.500 & 4.000 & 4.000 & 4.000 & 4.000 & 4.000 & 4.000 \\
\hline Calcium Carbonate & 1.600 & 0.770 & 0.590 & 0.770 & 0.59 & 0.770 & 0.590 \\
\hline Mono-Calcium Phosphate & 1.620 & 0.520 & 0.320 & 0.520 & 0.32 & 0.520 & 0.320 \\
\hline Premix & 0.300 & 0.300 & 0.300 & 0.300 & 0.30 & 0.300 & 0.300 \\
\hline Salt $(\mathrm{NaCl})$ & 0.300 & 0.300 & 0.300 & 0.300 & 0.30 & 0.300 & 0.300 \\
\hline HCL Lysine & 0.240 & 0.220 & 0.210 & 0.220 & 0.21 & 0.220 & 0.210 \\
\hline DL- Methionine & 0.230 & 0.230 & 0.230 & 0.230 & 0.23 & 0.230 & 0.230 \\
\hline Anti-mycotoxins & 0.100 & 0.100 & 0.100 & 0.100 & 0.10 & 0.100 & 0.100 \\
\hline Formi ${ }^{\circledR} D F$ (Sodium Di-Formate) & - & 0.150 & 0.150 & 0.225 & 0.225 & 0.300 & 0.300 \\
\hline Total & 100.000 & 100.000 & 100.000 & 100.00 & 100.00 & 100.000 & 100.000 \\
\hline Crude Protein \% & 21.04 & 21.06 & 21.09 & 21.06 & 21.09 & 21.05 & 21.08 \\
\hline Metabolizable Energy Kcal/ Kg & 3113 & 3134 & 3147 & 3131 & 3144 & 3129 & 3142 \\
\hline Calcium $\%$ & 0.900 & 0.452 & 0.360 & 0.452 & 0.360 & 0.452 & 0.360 \\
\hline Available Phosphorus \% & 0.450 & 0.225 & 0.180 & 0.225 & 0.184 & 0.225 & 0.184 \\
\hline Lysine \% & 1.25 & 1.25 & 1.25 & 1.25 & 1.25 & 1.25 & 1.25 \\
\hline Methionine \% & 0.60 & 0.60 & 0.60 & 0.60 & 0.60 & 0.60 & 0.60 \\
\hline Methionine + Cystein \% & 0.96 & 0.96 & 0.96 & 0.96 & 0.96 & 0.96 & 0.96 \\
\hline Price/ Ton (L.E.) & 3657 & 3608 & 3604 & 3626 & 3622 & 3643 & 3639 \\
\hline
\end{tabular}

Each 3 Kg of premix contains: Vitamins: A: 12000000 IU; Vit. D3 2000000 IU; E: $10000 \mathrm{mg} ; \mathrm{K3}: 2000 \mathrm{mg}$; B1:1000 mg; B2: $5000 \mathrm{mg}$; B6:1500 mg; B12: $10 \mathrm{mg}$; Biotin: $50 \mathrm{mg}$; Coline chloride: 250000 mg; Pantothenic acid: 10000 mg; Nicotinic acid: 30000 mg; Folic acid: 1000 mg; Minerals: Mn: 60000 mg; Zn: 50000 mg; Fe: 30000 mg; Cu: 10000 mg; I: 1000 mg; $\mathrm{Se}: 100 \mathrm{mg}$ and $\mathrm{Co}: 100 \mathrm{mg}$.

(T1):Control, (T2): $50 \% \mathrm{Ca} \& \mathrm{AP}$ requirements $+1.50 \mathrm{Kg} /$ ton $\mathrm{NDF} ;(\mathrm{T} 3): 40 \% \mathrm{Ca} \& \mathrm{AP}$ requirements $+1.50 \mathrm{Kg} /$ ton $\mathrm{NDF} ;(\mathrm{T} 4): 50 \% \mathrm{Ca} \& \mathrm{AP}$ requirements $+2.25 \mathrm{Kg} /$ ton $\mathrm{NDF}(\mathrm{T5})$ : $40 \% \mathrm{Ca} \& \mathrm{AP}$ requirements $+2.25 \mathrm{Kg} /$ ton $\mathrm{NDF} ;(\mathrm{T} 6): 50 \% \mathrm{Ca} \& \mathrm{AP}$ requirements $+3.00 \mathrm{Kg} /$ ton $\mathrm{NDF}$ and $(\mathrm{T7}): 40 \% \mathrm{Ca} \& \mathrm{AP}$ requirements $+3.00 \mathrm{Kg} /$ ton $\mathrm{NDF}$ 


\section{Abdelhady et al.}

Table (3). Effect of different dietary treatments on productive performance parameters of broilers ( 0 - 35 days of age).

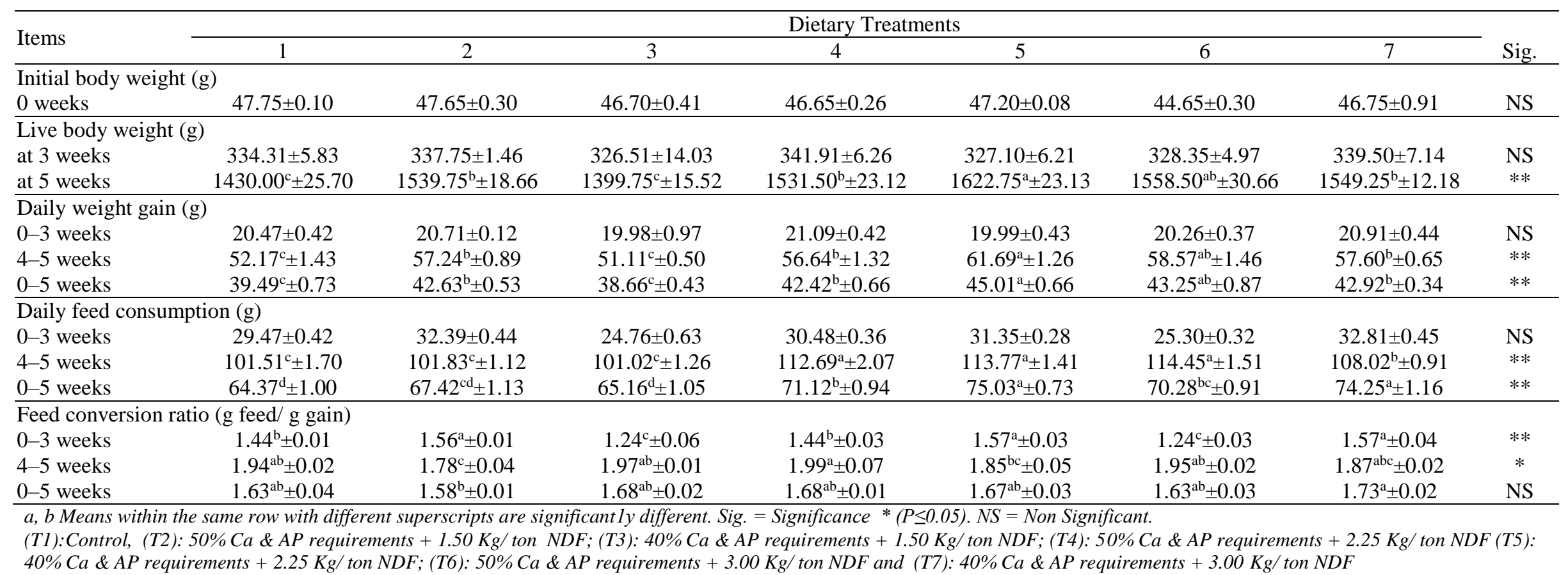

\section{Table (4). Effect of different dietary treatments on performance index (PI) and production efficiency factor (PEF).}

\begin{tabular}{|c|c|c|c|c|c|c|c|c|}
\hline \multirow{2}{*}{ Items } & \multicolumn{7}{|c|}{ Treatments } & \multirow[b]{2}{*}{ Sig } \\
\hline & 1 & 2 & 3 & 4 & 5 & 6 & 7 & \\
\hline Performance index ${ }^{1}$ & $87.92^{\mathrm{ab}} \pm 3.88$ & $97.39^{\mathrm{a}} \pm 1.47$ & $83.10^{\mathrm{b}} \pm 1.91$ & $91.56^{\mathrm{ab}} \pm 4.04$ & $97.49^{\mathrm{a}} \pm 3.57$ & $96.02^{\mathrm{a}} \pm 3.61$ & $89.63^{\mathrm{ab}} \pm 1.61$ & $*$ \\
\hline Production efficiency factor ${ }^{2}$ & $\begin{array}{c}251.22^{\mathrm{ab}} \\
\pm 11.09\end{array}$ & $\begin{array}{c}278.26^{\mathrm{a}} \\
\pm 4.22\end{array}$ & $\begin{array}{c}237.44^{\mathrm{b}} \\
\pm 5.44\end{array}$ & $\begin{array}{c}261.61^{\mathrm{ab}} \\
\pm 11.54\end{array}$ & $\begin{array}{l}278.55^{\mathrm{a}} \\
\pm 10.19\end{array}$ & $\begin{array}{l}274.35^{\mathrm{a}} \\
\pm 10.33\end{array}$ & $\begin{array}{c}256.08^{\mathrm{ab}} \\
\pm 4.61\end{array}$ & $*$ \\
\hline
\end{tabular}

$a, b, c$ Means within the same row with different superscripts are significantly different, Sig. =Significance * $(P<0.05)$. NS= Non Significant.1: North (1981), 2: Emmert (2000) (T1):Control, (T2): $50 \% \mathrm{Ca} \& \mathrm{AP}$ requirements $+1.50 \mathrm{Kg} /$ ton NDF; (T3): $40 \% \mathrm{Ca} \& \mathrm{AP}$ requirements $+1.50 \mathrm{Kg} /$ ton NDF; (T4): $50 \% \mathrm{Ca} \& \mathrm{AP}$ requirements $+2.25 \mathrm{Kg} /$ ton NDF (T5): $40 \% \mathrm{Ca} \& \mathrm{AP}$ requirements $+2.25 \mathrm{Kg} /$ ton $\mathrm{NDF} ;(\mathrm{T6}): 50 \% \mathrm{Ca} \& \mathrm{AP}$ requirements $+3.00 \mathrm{Kg} /$ ton $\mathrm{NDF}$ and $(\mathrm{T7}): 40 \% \mathrm{Ca} \& \mathrm{AP}$ requirements $+3.00 \mathrm{Kg} /$ ton $\mathrm{NDF}$ 
Egyptian J. Nutrition and Feeds (2015)

Table (5). Effect of different dietary treatments on protein conversion ratio (PCR) and energy conversion ratio (ECR).

\begin{tabular}{|c|c|c|c|c|c|c|c|c|}
\hline \multirow{2}{*}{ Items } & \multicolumn{8}{|c|}{ Dietary Treatments } \\
\hline & 1 & 2 & 3 & 4 & 5 & 6 & 7 & Sig. \\
\hline \multicolumn{9}{|c|}{ PCR. Protein conversion ratio (g protein/ g gain) } \\
\hline $0-3$ weeks & $0.31^{\mathrm{c}} \pm 0.01$ & $0.34^{\mathrm{b}} \pm 0.01$ & $0.34^{\mathrm{ab}} \pm 0.01$ & $0.32^{\mathrm{c}} \pm 0.01$ & $0.30^{\mathrm{c}} \pm 0.01$ & $0.30^{\mathrm{c}} \pm 0.01$ & $0.36^{\mathrm{a}} \pm 0.01$ & $* *$ \\
\hline 4-5 weeks & $0.39 \pm 0.01$ & $0.37 \pm 0.01$ & $0.37 \pm 0.01$ & $0.38 \pm 0.01$ & $0.38 \pm 0.01$ & $0.38 \pm 0.01$ & $0.37 \pm 0.01$ & NS \\
\hline $0-5$ weeks & $0.36^{\mathrm{ab}} \pm 0.01$ & $0.36^{\mathrm{a}} \pm 0.01$ & $0.36^{\mathrm{a}} \pm 0.01$ & $0.35^{\mathrm{ab}} \pm 0.01$ & $0.34^{\mathrm{b}} \pm 0.01$ & $0.34^{\mathrm{b}} \pm 0.01$ & $0.36^{\mathrm{a}} \pm 0.01$ & $* *$ \\
\hline \multicolumn{9}{|c|}{ ECR. Energy conversion ratio (1000 Kcal/g gain) } \\
\hline $0-3$ weeks & $41.19^{\mathrm{cd}} \pm 0.65$ & $44.81^{b} \pm 0.95$ & $45.85^{\mathrm{ab}} \pm 0.66$ & $42.06^{\mathrm{c}} \pm 0.79$ & $40.28^{\mathrm{cd}} \pm 0.87$ & $39.30^{\mathrm{d}} \pm 0.44$ & $47.78^{\mathrm{a}} \pm 0.87$ & $* *$ \\
\hline 4-5 weeks & $58.05 \pm 1.87$ & $55.31 \pm 0.64$ & $56.56 \pm 0.74$ & $57.14 \pm 1.01$ & $56.82 \pm 1.16$ & $57.72 \pm 1.29$ & $55.85 \pm 0.48$ & NS \\
\hline $0-5$ weeks & $49.62^{\mathrm{ab}} \pm 0.63$ & $50.06^{\mathrm{ab}} \pm 0.50$ & $51.21^{\mathrm{a}} \pm 0.69$ & $49.60^{\mathrm{ab}} \pm 0.71$ & $48.55^{\mathrm{b}} \pm 0.85$ & $48.51^{\mathrm{b}} \pm 0.86$ & $51.81^{\mathrm{a}} \pm 0.48$ & $*$ \\
\hline
\end{tabular}

$a, b, c$ Means within the same row with different superscripts are significantly different. Sig. $=$ Significance $* *(P \leq 0.01), N S=$ Non Significant.

(T1):Control, (T2): $50 \% \mathrm{Ca} \& \mathrm{AP}$ requirements $+1.50 \mathrm{Kg} /$ ton NDF; (T3): $40 \% \mathrm{Ca} \& \mathrm{AP}$ requirements $+1.50 \mathrm{Kg} /$ ton $\mathrm{NDF} ;(\mathrm{T} 4): 50 \% \mathrm{Ca} \& \mathrm{AP}$ requirements $+2.25 \mathrm{Kg} /$ ton $\mathrm{NDF}(\mathrm{T5})$ : $40 \% \mathrm{Ca} \& \mathrm{AP}$ requirements $+2.25 \mathrm{Kg} /$ ton $\mathrm{NDF} ;(\mathrm{T6}): 50 \% \mathrm{Ca} \& \mathrm{AP}$ requirements $+3.00 \mathrm{Kg} /$ ton NDF and (T7): $40 \% \mathrm{Ca} \& \mathrm{AP}$ requirements $+3.00 \mathrm{Kg} /$ ton $\mathrm{NDF}$

\section{Table (6). Effect of different dietary treatments on some of carcass characteristics and pH value of ileal contents (35 days of age).}

\begin{tabular}{|c|c|c|c|c|c|c|c|c|}
\hline \multirow{2}{*}{ Items } & \multicolumn{7}{|c|}{ Dietary Treatments } & \multirow[b]{2}{*}{ Sig. } \\
\hline & 1 & 2 & 3 & 4 & 5 & 6 & 7 & \\
\hline Dressing \% & $65.97 \pm 1.84$ & $68.29 \pm 1.24$ & $66.86 \pm 1.06$ & $66.55 \pm 1.60$ & $67.18 \pm 0.85$ & $63.82 \pm 0.30$ & $67.85 \pm 0.52$ & $\mathrm{NS}$ \\
\hline Liver \% & $3.17 \pm 0.05$ & $3.08 \pm 0.04$ & $3.50 \pm 0.04$ & $3.63 \pm 0.07$ & $3.80 \pm 0.05$ & $3.52 \pm 0.02$ & $3.95 \pm 0.04$ & NS \\
\hline Gizzard \% & $1.68 \pm 0.02$ & $1.68 \pm 0.03$ & $1.64 \pm 0.03$ & $2.01 \pm 0.03$ & $1.53 \pm 0.01$ & $1.54 \pm 0.05$ & $1.72 \pm 0.05$ & NS \\
\hline Heart $\%$ & $0.57 \pm 0.01$ & $0.48 \pm 0.01$ & $0.46 \pm 0.01$ & $0.58 \pm 0.01$ & $0.69 \pm 0.01$ & $0.44 \pm 0.01$ & $0.89 \pm 0.02$ & NS \\
\hline Giblets $\% *$ & $5.43 \pm 0.08$ & $5.25 \pm 0.05$ & $5.60 \pm 0.08$ & $6.24 \pm 0.06$ & $6.02 \pm 0.07$ & $5.50 \pm 0.06$ & $6.56 \pm 0.09$ & NS \\
\hline Ready to cook \% \# & $71.41 \pm 1.90$ & $73.54 \pm 1.27$ & $72.46 \pm 1.12$ & $72.79 \pm 1.58$ & $73.20 \pm 0.89$ & $69.32 \pm 0.24$ & $74.41 \pm 0.55$ & NS \\
\hline Abdominal Fat \% & $0.84 \pm 0.02$ & $1.39 \pm 0.02$ & $1.00 \pm 0.03$ & $1.06 \pm 0.04$ & $1.02 \pm 0.01$ & $1.37 \pm 0.03$ & $0.62 \pm 0.01$ & NS \\
\hline $\mathrm{pH}$ of ileal contents & $5.52^{\mathrm{b}} \pm 0.01$ & $4.99^{c} \pm 0.01$ & $5.72^{\mathrm{a}} \pm 0.01$ & $4.61^{\mathrm{d}} \pm 0.01$ & $4.51^{\mathrm{e}} \pm 0.01$ & $4.05^{\mathrm{g}} \pm 0.01$ & $4.28^{\mathrm{f}} \pm 0.01$ & $* *$ \\
\hline
\end{tabular}

$a, b, c, d, e, f, g$ Means within the same row with different superscripts are significantly different. Sig. $=$ Significance $* *(P \leq 0.01), N S=$ Non Significant.

$*$ Giblets $=$ Liver + Gizzard + Heart, \# Ready to Cook = Carcass Weight + Giblets

(T1):Control, (T2): $50 \% \mathrm{Ca} \& \mathrm{AP}$ requirements $+1.50 \mathrm{Kg} /$ ton $\mathrm{NDF} ;(\mathrm{T} 3): 40 \% \mathrm{Ca} \& \mathrm{AP}$ requirements $+1.50 \mathrm{Kg} /$ ton $\mathrm{NDF} ;(\mathrm{T} 4): 50 \% \mathrm{Ca} \& \mathrm{AP}$ requirements $+2.25 \mathrm{Kg} /$ ton NDF (T5): $40 \% \mathrm{Ca} \& \mathrm{AP}$ requirements $+2.25 \mathrm{Kg} /$ ton $\mathrm{NDF} ;(\mathrm{T6}): 50 \% \mathrm{Ca} \& \mathrm{AP}$ requirements $+3.00 \mathrm{Kg} /$ ton $\mathrm{NDF}$ and $(\mathrm{T7}): 40 \% \mathrm{Ca} \& \mathrm{AP}$ requirements $+3.00 \mathrm{Kg} /$ ton $\mathrm{NDF}$ 


\section{Abdelhady et al.}

Table (7). Effect of different dietary treatments on intestinal (ileum) bacterial count. (35 days of age).

\begin{tabular}{|c|c|c|c|c|c|c|c|}
\hline \multirow{2}{*}{ Items } & \multicolumn{7}{|c|}{ Dietary Treatments } \\
\hline & 1 & 2 & 3 & 4 & 5 & 6 & 7 \\
\hline Total Count Log & 10.27 & 8.82 & 8.78 & 8.66 & 8.42 & 9.10 & 8.87 \\
\hline Coli-form Count Log & 6.04 & 5.48 & 5.51 & 5.25 & 5.21 & 5.13 & 5.10 \\
\hline Lactic acid Count Log & 3.18 & 2.72 & 2.79 & 2.67 & 2.73 & 2.55 & 2.60 \\
\hline Salmonella Count Log & 1.65 & 1.65 & 1.55 & 1.45 & 1.50 & 1.28 & 1.33 \\
\hline
\end{tabular}

(T1):Control, (T2): $50 \%$ Ca \& AP requirements $+1.50 \mathrm{Kg} /$ ton $\mathrm{NDF} ;(\mathrm{T} 3)$. $40 \%$ Ca \& AP requirements $+1.50 \mathrm{~K}$

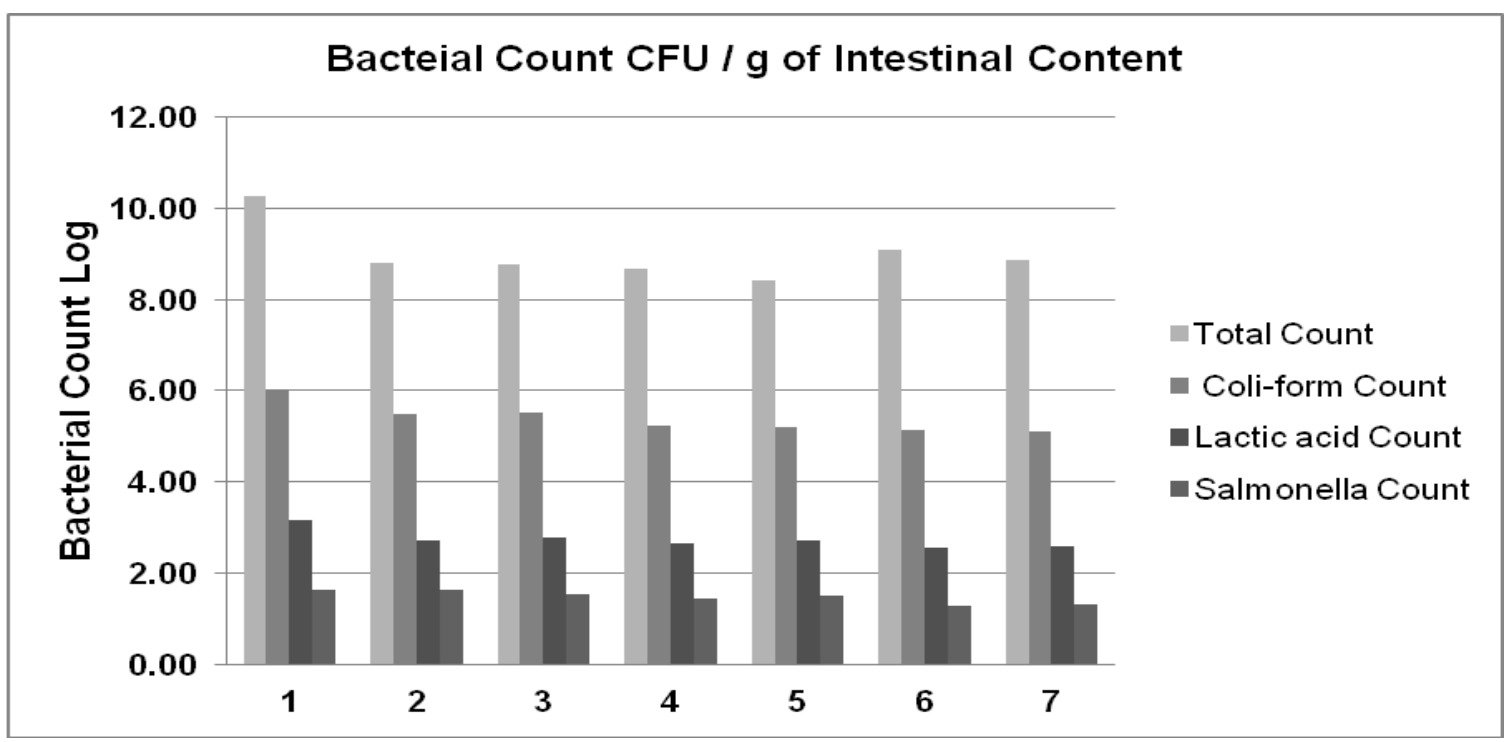

Figure (1). Effect of different dietary treatments on intestinal (ileum) bacterial count. (35 days of age). 
عبد الرحمن يوسف محمد عبدا لهادى؛ حسين عبدالله العلايلى؛ سيد عبد الرحمن إبراهيم و مروان عبدالعزيز محمود عبدالعزيز قسم إنتاج الدواجن ـ كلية الزراعة - جامعة عين شمس - شبرا الخيمة ـ القاهرة ـ مصر.

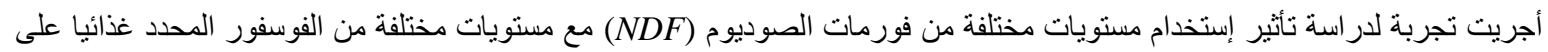

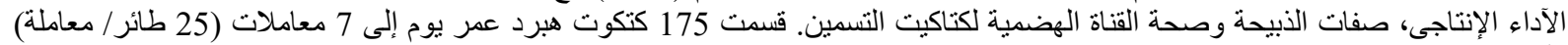

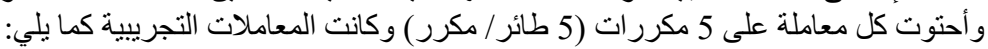

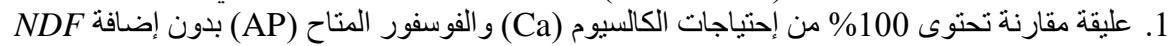

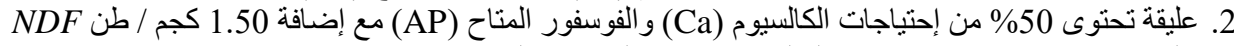

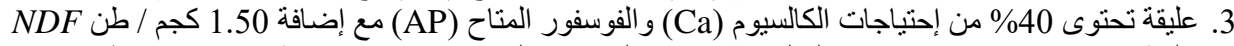

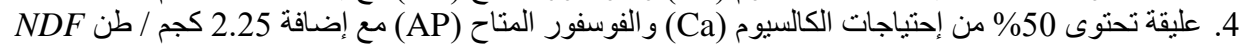

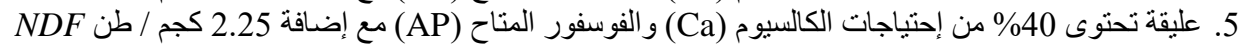

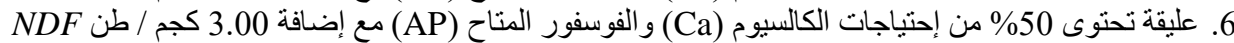
7. عليقة تحتوى 40\% من إحتباجات الكالسيوم (Ca) و الفوسفور المناح (AP) مع إضافة 3.00 كجم / طن

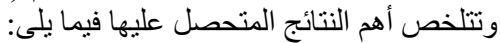

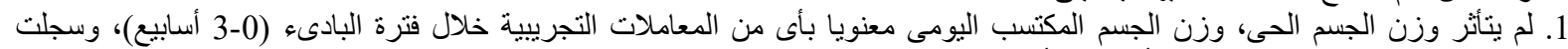

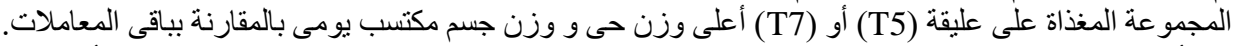

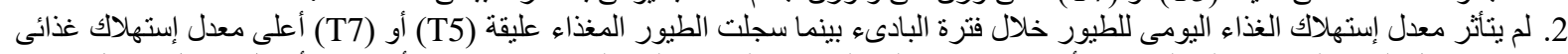

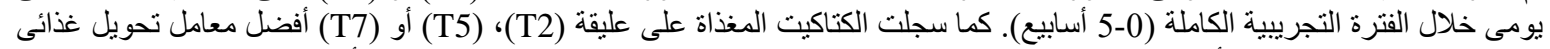

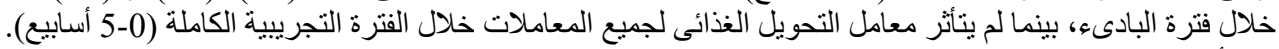
3. لم تتأثر قيم دليل الإنتاج وقيم معامل كفاءة الإنتاج معنويا بالمعاملات الغذائية المختلفة وظهرت جميعا متثابهة معنويا مع مجموعة المقارنة

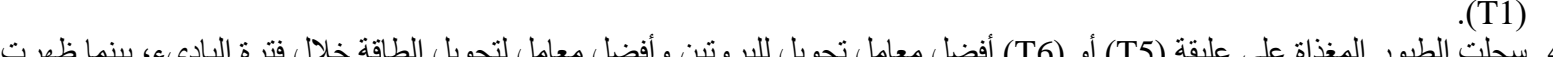

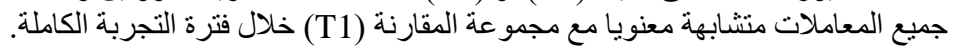

5.

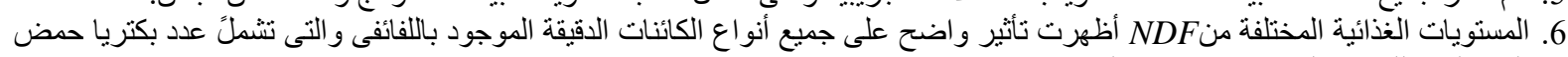

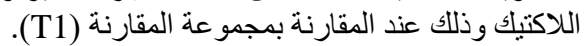

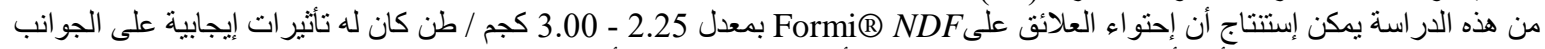
الدختلفة من الآداء الإنتاجى بدون أى تأثير سلبى على صفاء إلى الذبيحة أو العد البكتري فى الأمعاء. 